\title{
Mineralization of Garnierite in Morowali Nickel laterite deposit, Indonesia
}

\author{
YURI CHOI ${ }^{1}$, INSUNG LEE $^{1 *}$ AND JIHUN LEE ${ }^{1}$ \\ ${ }^{1}$ School of Earth and Environmental Sciences, Seoul \\ National University, Seoul, 08826, Korea Republic of \\ (*correspondence: insung@snu.ac.kr)
}

Nickel is useful base metal for secondary battery and metal alloy so it is expected to be mined more in the future. Until now the production of nickel is progressive in nickel sulfide type ore deposits because of its convenience for smelting of nickel. However, nickel laterite type deposits are recently standing out for the source of nickel ore called garnierite which contains high nickel concentration. Garnierite is $\mathrm{Mg}$ hydrous silicate mineral having amorphous jade green color. Garnierite is typically occurring in laterite deposits but little bit different by areas depending on which phases are dominant.

Nickel laterite deposits can be developed under tropical climate and where the ultramafic host rocks exist. Indonesia coincides with these condition in Sulawesi island. In Sulawesi, the Morowali nickel laterite deposit consists of lateritic layers from bottom to top: ultramafic bedrock, saprolite, limonite and ferruginous cap. The main ore mineral, garnierite, mineralized in the lower saprolite layer occurs as coating the surface of ultramafic rock. In addition, the garnierite found in this deposit has two different colors, jade green and grass green. In this study, we performed XRD and EPMA analysis to figure out which mineral phases are mixed in each different colored garnierites and where the nickel comes from. Through these analysis and microscopic observation we suggest the nickel mineralization processes how the Morowali nickel laterite deposits were made. 